\title{
Impact of disease on markers of micronutrient status
}

\author{
BY DAVID I. THURNHAM \\ Human Nutrition Research Group, School of Biomedical Sciences, University of Ulster, \\ Coleraine BT52 ISA
}

It is becoming increasingly well recognized that, although nutritional status of micronutrients is determined principally by diet, there are factors other than biological diversity which determine the concentration of a micronutrient in the blood in relation to the dietary intake.

In those halcyon days when nutrition was still 'simple', i.e. back in the 1930s-1950s, there were many investigators who worked on depletion-repletion experiments to determine nutritional requirements and at the same time obtained information on the relationships between dietary intake and biological markers of micronutrient status. These studies produced the 'nutritional bibles' of the 1960s (Interdepartmental Committee on Nutrition for National Defense, 1963; Sauberlich et al. 1974) which have guided workers in assessing micronutrient status and, with a few minor modifications, many of the criteria are still in use today. However, the big drawback of these studies was that most were done on young fit men and women who were monitored closely throughout depletion and at the first clinical sign of deficiency or disease, the subjects were usually replenished, to determine the amount of nutrient required to restore normality. Hence, the information obtained related to an unnatural situation where a healthy subject was deprived of a single nutrient.

The unnatural basis for these experiments was well recognized. Numerous workers point out that diets are not usually deficient in a single nutrient and healthy subjects do not get deficiency diseases. Nevertheless, the information on thresholds of acceptability of blood biomarkers obtained by these unnatural experiments continues to be used in the real world and information extrapolated from them to derive dietary intakes. However, the dangers of this blind acceptance of dietary predictions are starting to become apparent. Epidemiologists and others are drawing conclusions on diet-disease relationships from information of blood biomarkers. For example, the enthusiasm for $\beta$-carotene intervention studies arose from consistent information which suggested that because smokers had lower levels of plasma $\beta$-carotene, this suggested that dietary intake of $\beta$-carotene was also low (Connett et al. 1989). However, this was done without a real understanding of what factors other than diet influence plasma $\beta$-carotene in smokers. However, if a particular disease or traumatic condition can itself influence the relationship between the blood biomarkers and diet, then diet may not be a factor in the aetiology of the disease at all. It is becoming more and more apparent that disease does influence blood nutrient levels in various ways. These factors have to be recognized and ways found to discriminate between the influence of disease and diet on blood biomarkers.

\section{VITAMIN A}

Retinol or vitamin A is probably the best example of a nutrient influenced by disease. It is well accepted that the circulating concentration of retinol is not related to dietary intake, except when the amount in the blood is low (approximately $<0.7 \mu \mathrm{mol} / /$; Olson, 1984). Nevertheless, it appears that at all concentrations the amount in the blood is influenced by diseases. We first realized this when studying patients with malaria from two different 
socio-economic groups and their respective controls (Thurnham \& Singkamani, 1991). Irrespective of the difference in circulating retinol between the two groups without infection, the influence of malaria was similar, producing almost the same absolute reduction in retinol levels between the respective groups (Table 1).

This particular study of malaria was cross-sectional and we were uncertain of the preinfection retinol values. However, a longitudinal study by Reddy et al. (1986) clearly demonstrated a fall in circulating retinol during infection with measles; the levels returning to the pre-measles levels after infection without vitamin A supplementation (Table 2).

The study by Reddy et al. (1986) clearly demonstrated that clinical disease reduces plasma retinol and such work illustrates that any conclusions drawn about vitamin A status on the basis of plasma retinol in clinical disease can at best be only tentative. However, a runny nose, loose stools or mild respiratory symptoms may be so common as to be regarded as normal. Do they also influence blood nutrient levels? Subclinical or occult disease is widespread in subgroups of the population in both the First and Third Worlds. In a recent malaria survey in the eastern part of India, workers found $30 \%$ of the children (111 years) showed blood-smear positivity for malaria and, while $75 \%$ of these showed no clinical evidence of disease (Ghosh et al. 1995), there was evidence of abnormality with three acute-phase proteins: albumin $(P<0.05)$ ferritin $(P<0.05)$ and caeruloplasmin (not significant). Likewise Filteau et al. (1993) found $57 \%$ (twenty-eight of forty-nine subjects) of Ghanian children (6-59 months) who had abnormally raised levels of the acute-phase protein, $\alpha_{1}$-acid glycoprotein, to be asymptomatic.

Table 1. Retinol concentrations ( $\mu$ mol $/$ ) in malaria patients and control subjects in rural and urban communities in Thailand (Data from Thurnham \& Singkamani, 1991)

(Values are medians and ranges)

\begin{tabular}{ccccc}
\hline \hline Group & & Malaria & Control & Difference \\
\hline Urban & $n$ & 24 & 27 & \\
& Median & $1.17^{\mathrm{a}}$ & $1.76^{\mathrm{b}}$ & 0.59 \\
& Range & $0.61-2.97$ & $0.66-3.33$ & \\
Rural & $n$ & 21 & 20 & 0.64 \\
& Median & $0.50^{\mathrm{c}}$ & $1.14^{\mathrm{a}}$ & \\
& Range & $0 \cdot 10-1.20$ & $0.17-2.15$ & \\
\hline
\end{tabular}

a,b,c, Median values with unlike superscript letters were significantly different $(P<0.001$ by Kruskall-Wallis; $P<0.05$ by Scheffe group test).

Table 2. Influence of measles on serum retinol and retinol-binding protein (RBP) concentrations

(Values are means with their standard errors)

\begin{tabular}{|c|c|c|c|c|c|}
\hline \multirow[t]{2}{*}{ Group } & \multicolumn{2}{|c|}{ Retinol* $(\mu \mathrm{mol} / \mathrm{l})$} & \multicolumn{2}{|c|}{$\mathrm{RBP}^{*}(\mu \mathrm{mol} / \mathrm{h})$} & \multirow[t]{2}{*}{ Retinol : RBP } \\
\hline & Mean & SE & Mean & $\overline{S E}$ & \\
\hline Pre-infection (n 117) & 0.73 & 0.03 & 1.19 & 0.29 & 0.61 \\
\hline During infection $\dagger$ ( $n$ 153) & 0.47 & 0.02 & 1.00 & 0.33 & 0.47 \\
\hline Post-infection ( $n$ 108) & 0.89 & 0.02 & 1.19 & 0.29 & 0.68 \\
\hline
\end{tabular}

*Recalculated from original data of Reddy et al. (1986) using molecular weights of 245 and 21000 for retinol and RBP respectively.

†Values recorded during infection were significantly different from both pre- and post-infection values for both retinol and RBP. 
Table 3. Sensitivity and specificity of conjunctival impression cytology (CIC) in relation to plasma retinol in various studies

\begin{tabular}{|c|c|c|c|c|}
\hline Reference & Country & Retinol threshold $(\mu \mathrm{mol} / \mathrm{l})$ & Sensitivity (\%) & Specificity (\%) \\
\hline Natadisastra et al. (1988) & Indonesia* & $<0.70$ & 61.8 & $88 \cdot 5$ \\
\hline Gadomski et al. (1989) & Guatemala* & $<0.70$ & 26 & 81 \\
\hline Stolzfus et al. (1993) & Indonesia* & $<0.52$ & 40 & 89 \\
\hline Carlier et al. (1991) & Senegal† & $<0.35$ & 39.7 & 70 \\
\hline Carlier et al. (1992) & Senegal $\varphi_{t}^{+}$ & $<0.35$ & $74 \cdot 0$ & 48 \\
\hline \multirow[t]{2}{*}{ Chowdhury et al. (1996) } & Indiaf & $<0.70$ & $90 \cdot 6$ & 100 \\
\hline & & $<0.35$ & 100 & 59 \\
\hline
\end{tabular}

*Used CIC technique.

$\dagger$ Used CIC with transfer technique.

$\$$ Best results following evaluation of different ways of classifying abnormal CIC results.

Plasma levels of circulating retinol are controlled by the level of retinol-binding protein (RBP; Kanai et al. 1968). As this is a negative acute-phase protein (Rosales et al. 1996), concentrations of plasma retinol will fall in disease, possibly to minimize urinary losses of retinol. Retinol losses during infection and in severe disease can be as high as half the recommended daily allowance (Stephensen et al. 1994). RBP and retinol probably appear in the urine as a consequence of the increased endothelial permeability (Areekul, 1988; Gosling et al. 1991) which accompanies infection and increases macromolecule exchange between the plasma and the extracellular fluid compartments and also the potential for increased losses of plasma proteins in the urine (Sandberg et al. 1985; Shearman \& Gosling, 1988). In a well-fed person, a temporary decline in circulating retinol may not be too crucial, but the problem arises when the patient is not well-nourished at the outset and disease becomes chronic.

In Third World situations where people are living in unhygienic conditions and food is frequently contaminated with pathogens, disease is common and consequently levels of circulating retinol may be dangerously low for long periods. Low levels of retinol are probably responsible for the abnormalities in ocular epithelium which have been reported by many workers (Carlier et al. 1992; Nathanail \& Powers, 1992; Stolzfus et al. 1993; Chowdhury et al. 1996). Ocular abnormalities have been demonstrated using conjunctival impression cytology (CIC) and results obtained by CIC have been compared with plasma retinol levels to assess sensitivity and specificity of CIC to measure vitamin A status. While some workers report good agreement between the two methods (Chowdhury et al. 1996; Table 3), other workers in different environments have not obtained good agreement (Natadisastra et al. 1988; Gadomski et al. 1989; Carlier et al. 1991, 1992; Stolzfus et al. 1993; Table 3). The probable reason for the lack of agreement is that while plasma retinol responds very rapidly to changes in vitamin A intake, the re-appearance of goblet cells in the ocular epithelium may take 3-8 weeks (Wittpenn et al. 1986).

CIC is a relatively non-invasive technique but it involves a certain amount of subjectivity and it is difficult to perform in young children (Nathanail \& Powers, 1992; Chowdhury et al. 1996). In contrast, the fact that the level of retinol is determined by the disease activity raises the possibility that retinol may be evaluated by comparison with an independent disease marker, i.e. an acute-phase protein. Filteau et al. (1993) have reported correlations between plasma retinol and $\alpha_{1}$-acid glycoprotein $(r-0.35)$ and retinol and serum amyloid A $(r-0 \cdot 20)$. Sensitivity and specificity, however, were not as good as CIC when compared with the results of Chowdhury et al. (1996), but, of course, acute-phase 
Table 4. Sensitivity and specificity of raised $\alpha_{1}$-acid glycoprotein $*$ as an indication of the effect of disease on retinol levels

(Data from Filteau et al. 1993)

\begin{tabular}{ccc}
\hline \hline Retinol threshold $(\mu \mathrm{mol} / 1)$ & Sensitivity $(\%)$ & Specificity (\%) \\
\hline$<0.35$ & 86 & 36 \\
$<0.70$ & 72 & 40 \\
\hline
\end{tabular}

*An abnormal $\alpha_{1}$-acid glycoprotein is defined as $>1 \mathrm{~g} / \mathrm{l}$ (Filteau et al. 1993).

proteins are synthesized in response to a stress. Different stresses undoubtedly influence different proteins in different ways and it is probably unlikely that any acute-phase protein will behave exactly like RBP. However, the acute-phase protein will give some indication of whether disease might be having any influence on the retinol levels (Table 4).

\section{VITAMIN E}

In the same way that vitamin $A$ is influenced by its transport protein in disease, there is evidence that vitamin $E$ is influenced by the lipoproteins (Das et al. 1996). The lipoproteins, however, are larger molecules than RBP so the disease has to be severe enough to increase endothelial permeability sufficiently to influence circulating lipoprotein concentrations.

Malaria is a sufficiently severe disease to reduce plasma vitamin E concentrations (Thurnham et al. 1990; Das et al. 1996; Adelekan et al. 1997), but the fact that vitamin $\mathrm{E}$ : cholesterol in malaria-infected patients is not different from that of matched controls in studies done in three countries, Thailand (Thurnham et al. 1990), Nigeria (Adelekan et al. 1997) and India (Das et al. 1996), suggests that malaria influences vitamin E via the lipoproteins and not directly (Table 5). Of course, it is widely held that vitamin $\mathrm{E}$ is an important antioxidant and that in a disease like malaria, vitamin $\mathrm{E}$ would be under intense pressure from oxidizing free radicals both from the parasites and the inflammatory response of the disease. However, even in patients with severe malaria, as defined by World Health Organization (1990) criteria, vitamin E : cholesterol remained normal (Das et al. 1996; Table 5).

It would seem unlikely, therefore, that a subclinical condition, i.e. an increased risk of IHD, would influence plasma vitamin E. However, there is evidence from the World Health Organization MONICA (monitoring trends and determinants of cardiovascular disease) studies that lipid-corrected plasma vitamin $\mathrm{E}$ is significantly lower in those countries where the risk of IHD is higher (Gey et al. 1991). Likewise, Riemersma et al. (1991) have reported that persons with newly-diagnosed angina had significantly lower vitamin $E$ than age-matched controls. It is well established that subclinical heart disease is associated with abnormal acute-phase markers e.g. low albumin (Phillips et al. 1989; Kuller et al. 1991; Gillum \& Makuc, 1992), elevated fibrinogen (Yarnell et al. 1991) and leucocyte counts (Sipe, 1985), thus it is possible that subclinical disease may in some way reduce the available vitamin E. Furthermore, there is also some evidence which suggests that vitamin E supplementation was of benefit in preventing new attacks of IHD in a secondary prevention trial (Stephens et al. 1996). Nevertheless, a study from my own laboratory, which examined blood from 200 randomly-selected subjects in Belfast and Toulouse, found absolutely no difference in either vitamin $E$ or vitamin $E$ : cholesterol between the 


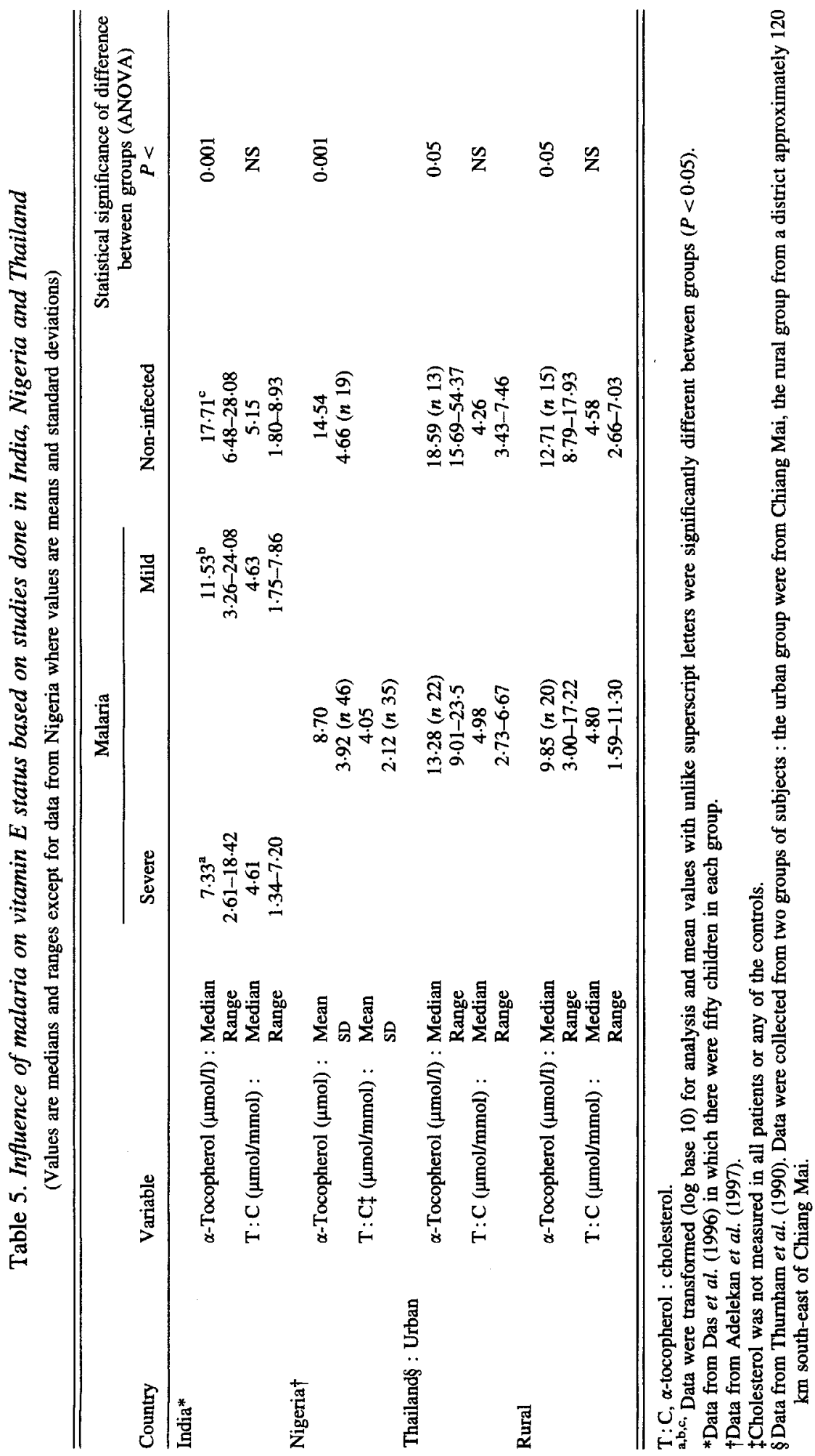


Table 6. Changes in leucocyte ascorbic acid during infection with the common cold (Data from Hume \& Weyers, 1973)

(Mean values and standard deviations; values are expressed as nmol $/ 10^{8}$ leucocytes, where $90 \mathrm{nmol} / 10^{8}$ leucocytes is equivalent to $16 \mu \mathrm{g}$ ascorbate $/ 10^{8}$ leucocytes)

\begin{tabular}{lcccccc}
\hline & \multicolumn{5}{c}{ Subject no. } & \\
\cline { 2 - 7 } Day of study & $1^{*}$ & 2 & 3 & 4 & Mean & SD \\
\hline Pre-cold & 140 & 106 & 96 & 114 & 114 & 19 \\
1 & 60 & 55 & - & 59 & 58 & 53 \\
2 & 48 & 46 & 87 & - & 60 & 23 \\
3 & 83 & 67 & 93 & 84 & 82 & 11 \\
4 & 123 & 90 & 97 & 119 & 107 & 16 \\
5 & 160 & - & - & 83 & - & - \\
10 & 152 & 126 & 97 & 121 & 124 & 23 \\
\hline
\end{tabular}

*Subject developed the cold while consuming $200 \mathrm{mg}$ vitamin $\mathrm{C} / \mathrm{d}$.

two centres in either men or women (Thurnham et al. 1994). These centres were MONICA study centres and were chosen because there is a three- to fourfold difference in IHD risk between them.

\section{VITAMIN C}

I will deal with vitamin $\mathrm{C}$ relatively briefly as I recently reviewed the peculiar relationship between vitamin $C$ and trauma (Thurnham, 1994). Briefly, disease appears to have a major impact on vitamin $C$ in the blood. In the 1960 s and early 1970 s it was shown that trauma rapidly reduced leucocyte ascorbic acid (LAA; Irvin et al. 1978; Vallance, 1986). The study of Hume \& Weyers (1973) shows the precipitous fall in LAA on day 1 following the onset of symptoms of the common cold (Table 6) and the subsequent behaviour over the next $5 \mathrm{~d}$ when pre-infection LAA concentrations were usually regained. In contrast, or as a consequence, plasma ascorbate appears to remain low throughout the period of infection (Thurnham, 1994).

The mechanism behind the fall in LAA is again associated with the acute-phase response and the leucocytosis, which is one of the very early effects of the acute-phase response (Sipe, 1985). Of the new leucocytes, $70 \%$ are neutrophils and these emerge from the bone marrow containing low levels of vitamin $\mathrm{C}$. In vitro experiments have shown that neutrophils avidly take up vitamin $\mathrm{C}$ in a process which is active, temperature-dependent (with a maximum at $40^{\circ}$ ) and accelerated a further 2.5 times if the neutrophils are antigenstimulated (Moser \& Weber, 1984). The reason for the uptake of vitamin C is not known. There are three possible explanations: (1) to improve the antioxidant defence of the new neutrophil, (2) to act as a means of transporting the vitamin $C$ to a tissue site where inflammation and tissue damage is occurring or (3) to remove a potential pro-oxidant from the plasma.

Of the three possible explanations, I favour the third one. The first possibility seems least likely since if newly-emerging neutrophils require vitamin $\mathrm{C}$ for the maintenance of their integrity, why is it not acquired during production? In fact, a recent report demonstrated that the production of oxygen free radicals by neutrophils from patients who recently had an acute myocardial infarction was depressed by vitamin $\mathbf{C}$ supplements (Herbaczynska-Cedro et al. 1995). The authors suggested that this would benefit the patient, since various measures of myocardial injury appeared to be positively correlated to 
neutrophil excitation, but one wonders what would happen if the patient developed an infection during treatment. Likewise, if neutrophils were needed to transport vitamin $C$ to the tissues, why are they not prepared in the bone marrow ready for this function? In contrast, vitamin $\mathrm{C}$ is known to be a pro-oxidant in the presence of Fe. At times of health the amount of free $\mathrm{Fe}$ in the blood will be at a minimum since there is adequate binding capacity in plasma in the form of transferrin. At times of trauma, however, free $\mathrm{Fe}$ in the form of bleomycin-detectable Fe, has been reported (Buffinton et al. 1986; Halliwell et al. 1988; Beare \& Steward, 1996). In addition, caeruloplasmin is increased to favour the production of $\mathrm{Fe}^{3+}$, the high $\mathrm{Fe}$-binding capacity protein, apoferritin, is increased and receptor activity in the reticulo-endothelial system is stimulated to promote Fe uptake (Herbert et al. 1996). Vitamin C would counter the effects of caeruloplasmin and leach $\mathrm{Fe}$ from ferritin so this is a further reason why plasma vitamin $\mathrm{C}$ concentrations would decrease in response to disease. The nature of the disease or the influence of disease severity in reducing plasma vitamin $\mathrm{C}$ are not known. However, there is evidence that subclinical disease (Bates et al. 1982, 1983) or mild trauma, such as smoking (Kallner et al. 1981), depresses plasma vitamin C, as discussed elsewhere (Thurnham, 1994).

\section{WATER-SOLUBLE B-VITAMINS}

The majority of the B-vitamins are present in the tissues in the form of co-enzymes. Riboflavin, thiamin and niacin are closely involved in mitochondrial functions and oxidation-reduction mechanisms, pyridoxine is closely associated with protein turnover and folate and cyanocobalamin with DNA replication, cell turnover and haemopoiesis. These functions may be strongly influenced by disease. Anorexia may stimulate a need for alternative fuels for energy needs which are obtained by tissue catabolism. Fever raises the BMR by $10 \%$ for every $1^{\circ}$ rise in temperature (Du Bois, 1948). Hyperplasia of cells of the immune system will stimulate DNA turnover. While it is apparent that requirements for these nutrients may be increased by the disease, there are only a limited number of studies which have measured the impact of disease on biomarkers of nutritional status of the different nutrients.

\section{Riboflavin}

One of the best methods of assessing riboflavin status is the erythrocyte glutathione reductase ( $E C$ 1.6.4.2; EGR) test in which the level of in vitro stimulation of EGR by the co-enzyme of riboflavin, is assessed as an activity coefficient (AC; Tillotson \& Baker, 1972). The degree of co-enzyme saturation of EGR is determined by the availability of riboflavin at the time of erythropoiesis, but as the erythrocyte is permeable to riboflavin, riboflavin status can be influenced by a sudden influx of riboflavin into the circulation. One of the consequences of tissue breakdown and a negative $\mathrm{N}$ balance is a release of tissue coenzymes into the circulation and an apparent increase in riboflavin status (Bates et al. 1981; Bamji et al. 1987).

\section{Thiamin}

Beriberi is one of those deficiency diseases which appears to be increased by an infection or fever (Platt, 1958). As indicated previously, fever will increase thiamin requirements (Du Bois, 1948) and, of course, this vitamin is of fundamental importance in the metabolism of glucose to provide energy via the Krebs cycle. There is also experimental 
evidence to suggest that the cytokine, which triggers anorexia during infection, alters food selection in favour of carbohydrate in preference to fat or protein (Macdonald et al. 1993).

Thiamin status is measured either by the erythrocyte transketolase (EC 2.2.1.1; TKL) assay (Brin, 1964) or by erythrocyte thiamin (Finglas, 1993). As in effect almost all erythrocyte thiamin is present as thiamin pyrophosphate and bound to transketolase, both methods are measuring the same component. The TKL assay is probably more sensitive than erythrocyte thiamin but apo-transketolase is unstable both in vivo and in vitro. Consequently, a chronic thiamin deficiency is less likely to be detected by the TKL assay, but the greater or longer the deficiency, the more difficult it is to measure total erythrocyte thiamin accurately.

\section{MINERALS}

Plasma concentrations of metal ions are frequently measured as markers of nutritional status, but their usefulness is questionable. Infection is commonly associated with a fall in plasma $\mathrm{Zn}$ and an increase in plasma $\mathrm{Cu}$ (Graham et al. 1991). The fall in $\mathrm{Zn}$ is a relatively rapid effect of infection but its function is not known. Plasma $\mathrm{Zn}$ represents less than $1 \%$ of total body $\mathrm{Zn}$ in comparison with $60 \%$ in the muscles and $20-30 \%$ in the bone (Aggett \& Favier, 1993). Thus, in catabolic conditions like infection, severe malnutrition or increased bone turnover, plasma $\mathrm{Zn}$ concentrations may be restored and normalized.

Plasma $\mathrm{Cu}$ can also be increased by tissue breakdown (Chevion et al. 1993), but the principal cause of the increase in plasma $\mathrm{Cu}$ with infection is the increased production of the acute-phase protein, caeruloplasmin (Koj, 1974). As indicated elsewhere, the ferroxidase (EC 1.16.3.1) activity of caeruloplasmin may be particularly important for the conversion of $\mathrm{Fe}^{2+}$ to $\mathrm{Fe}^{3+}$ to assist the uptake and removal of $\mathrm{Fe}$ from plasma during infection (Thurnham, 1994). The increase in caeruloplasmin, therefore, has little relationship with $\mathrm{Cu}$ status.

Iodine deficiency is a major public health problem in the Third World. Iodine is necessary for the synthesis of thyroid hormones and frequently these hormones are used as functional markers of iodine status. However, infection has pronounced effects on thyroid hormones, since they are transported in the blood by the negative acute-phase protein, transthyretin (TTR). The synthesis of TTR is markedly suppressed by infection (Ramsden et al. 1978; Dickson et al. 1982), thus thyroid hormone levels measured in communities where infection is common should be interpreted with caution. Whether such measurements can be better assessed using other acute-phase proteins to detect infection, as suggested for retinol, remains to be investigated.

The last mineral I want to discuss is Se. Se is an integral part of the enzyme glutathione peroxidase (EC 1.11.1.9; GPx) which catalyses the reduction of peroxides (Rotruck $\mathrm{et}$ al. 1973), but is also involved in thyroid metabolism (Arthur \& Beckett, 1994). Both metabolic functions are likely to be influenced by infection. There is some evidence to suggest that GPx activity in the lungs can be induced by exposure to elevated oxygen stress as, for example, in rats exposed to increased amounts of ozone (Chow, 1976). However, I know of no evidence that infection will induce similar changes, and tissue culture experiments suggest that superoxide dismutase (EC 1.15.1.1) activity is the more critical enzyme in coping with oxygen radicals.

\section{CONCLUSIONS}

Infection has pronounced effects on markers of micronutrient status. In particular, plasma retinol, $\alpha$-tocopherol and ascorbate are reduced by trauma. The effects can be linked to the 
acute-phase response and the changes may represent mechanisms designed to protect the host or his micronutrient reserves in the short term. The reductions in retinol and vitamin $\mathrm{E}$ can be associated with the reductions in their plasma transport proteins, while vitamin $\mathrm{C}$ levels are inversely related to the leucocytosis in trauma. Catabolic states may increase the availability of certain B-vitamins or minerals in the blood and produce an apparent improvement in status. The effects of infection on mineral status are variable. Changes in acute-phase proteins, for example the increase in $\mathrm{Cu}$-containing caeruloplasmin or the reduction in thyroid hormone-transporting transthyretin, are direct responses to infection, and care should be taken where these markers are used to interpret nutritional status.

\section{REFERENCES}

Adelekan, D. A., Adeodu, O. O. \& Thurnham, D. I. (1997). Comparative effects of malaria and malnutrition on plasma concentrations of antioxidant micronutrients in children. Annals of Tropical Paediatrics (In the Press). Aggett, P. J. \& Favier, A. (1993). Zinc. International Journal of Vitamin and Nutrition Research 63, 301-307. Areekul, S. (1988). Transcapillary escape rate and capillary permeability to albumin in patients with Plasmodium falciparum. Annals of Tropical Medicine and Parasitology 82, 135-140.

Arthur, J. R. \& Beckett, G. J. (1994). New metabolic roles for selenium. Proceedings of the Nutrition Society 53, 615-624.

Bamji, M. S., Bhaskaram, P. \& Jacob, C. M. (1987). Urinary riboflavin excretion and erythrocyte glutathione reductase activity in pre-school children suffering from upper respiratory tract infections and measles. Annals of Nutrition and Metabolism 31, 191-196.

Bates, C. J., Prentice, A. M., Paul, A. A., Sutcliffe, B. A., Watkinson, M. \& Whitehead, M. (1981). Riboflavin status in Gambian pregnant and lactating women and its implications for recommended dietary allowances. American Journal of Clinical Nutrition 34, 928-935.

Bates, C. J., Prentice, A. M., Paul, A. A. \& Whitehead, R. G. (1982). Seasonal variations in ascorbic acid status and breast milk ascorbic acid levels in rural Gambian women in relation to dietary intake. Transactions of the Royal Society of Tropical Medicine and Hygiene 76, 341-347.

Bates, C. J., Prentice, A. M., Prentice, A., Lamb, W. H. \& Whitehead, R. G. (1983). The effect of vitamin C supplementation on lactating women in Keneba, a West African rural community. International Journal of Vitamin and Nutrition Research 53, 68-76.

Beare, S. \& Steward, W. P. (1996). Plasma free iron and chemotherapy toxicity. Lancet 347, 342-343.

Brin, M. (1964). Erythrocyte as a biopsy tissue for functional evaluation of thiamine adequacy. Journal of the American Medical Association 187, 762-766.

Buffinton, G. D., Cowden, W. B., Hunt, N. H. \& Clark, I. A. (1986). Bleomycin-detectable iron in plasma from Plasmodium vinkei vinkei-infected mice. FEBS Letters 195, 65-67.

Carlier, C., Coste, J., Etchepare, M. \& Amedee-Manesme, O. (1992). Conjunctival impression cytology with transfer as a field-applicable indicator of vitamin A status for mass screening. International Journal of Epidemiology 21, 373-380.

Carlier, C., Moulia-Pelat, J. P., Ceccon, J. F., Mourey, M. S., Malvy, D., Fall, M., Diaye, M. N. \& AmedeeManesme, O. (1991). Prevalence of malnutrition and vitamin A deficiency in the Diurbel, Fatick and Kaolack regions of Senegal: a controlled study. American Journal of Clinical Nutrition 53, 74-77.

Chevion, M., Jiang, Y., Har-El, R., Berenshtein, E., Uretzky, G. \& Kitrossky, N. (1993). Copper and iron are mobilized following myocardial ischemia: Possible predictive criteria for tissue injury. Proceedings of the National Academy of Sciences USA 90, 1102-1106.

Chow, C. K. (1976). Biochemical responses in lungs of ozone-tolerant rats. Nature 260, 721-722.

Chowdhury, S., Kumar, R., Ganguly, N. K., Kumar, L., Nain, C. K. \& Walia, B. N. S. (1996). Conjunctival impression cytology with transfer (CICT) to detect pre-clinical vitamin A deficiency among slum children in India. British Journal of Nutrition 75, 785-790.

Connett, J. E., Kuller, L. H., Kjelsberg, M. O., Polk, B. F., Collins, G., Rider, A. \& Hulley, S. B. (1989). Relationship between carotenoids and cancer. The multiple risk factor intervention trial (MRFT) study. Cancer 64, 126-134.

Das, B. S., Thurnham, D. I. \& Das, D. B. (1996). Plasma $\alpha$-tocopherol, retinol and carotenoids in children with falciparum malaria. American Journal of Clinical Nutrition 64, 94-100.

Dickson, P. W., Howlett, G. J. \& Schreiber, G. (1982). Metabolism of prealbumin and changes induced by acute inflammation. European Journal of Biochemistry 129, 289-293.

Du Bois, E. F. (1948). Fever and the Regulation of Body Temperature. Springfield IL: Charles C. Thomas

Filteau, S. M., Morris, S. S., Abbott, R. A., Tomkins, A. M., Kirkwood, B. R., Arthur, P., Ross, D. A., Gyapong, J. O. \& Raynes, J. G. (1993). Influence of morbidity on serum retinol of children in a community-based study in northern Ghana. American Journal of Clinical Nutrition 58, 192-197. 
Finglas, P. M. (1993). Thiamin. International Journal of Vitamin and Nutrition Research 63, 270-274.

Gadomski, A. M., Kjolhede, C. L., Wittpenn, J., Rosas, A. R. \& Forman, M. R. (1989). Conjunctival impression cytology (CIC) to detect sub-clinical vitamin A deficiency: comparison of CIC with biochemical assessments. American Journal of Clinical Nutrition 49, 495-500.

Gey, K. F., Puska, P., Jordan, P. \& Moser, U. K. (1991). Inverse correlation between plasma vitamin E and mortality from ischemic heart disease in cross-cultural epidemiology. American Joumal of Clinical Nutrition 53, 326S-334S.

Ghosh, S. K., Yadav, R. S., Das, B. S. \& Sharma, V. P. (1995). Influence of nutritional and haemoglobin status on malaria infection in children. Indian Journal of Paediatrics 62, 321-326.

Gillum, R. F. \& Makuc, D. M. (1992). Serum albumin, coronary heart disease, and death. American Heart Journal 123, 507-513.

Gosling, P., Andrews, D. H. \& Chesner, I. M. (1991). Effect of anti-inflammatory drugs on urinary microalbumin excretion. Lancet 337, 855 .

Graham, N. M. H., Sorensen, D., Odaka, N., Brookmeyer, R., Chan, D., Willett, W. C., Morris, J. S. \& Saah, A. J. (1991). Relationship of serum copper and zinc levels to HIV-1 seropositivity and progression to AIDS. Journal of Acquired Immune Deficiency Syndromes 4, 976-980.

Halliwell, B., Aruoma, O. I., Mufti, G. \& Bomford, A. (1988). Bleomycin-detectable iron in serum from leukaemic patients before and after chemotherapy. FEBS Letters 241, 202-204.

Herbaczynska-Cedro, K., Klosiewicz-Wasek, B., Cedro, K., Wasek, W., Panczenko-Kresowska, B. \& Wartanowicz, M. (1995). Supplementation with vitamin C and vitamin E suppresses leukocyte oxygen free radical production in patients with myocardial infarction. European Heart Journal 16, 1044-1049.

Herbert, V., Shaw, S. \& Jayatilleke, E. (1996). Vitamin C-driven free radical generation from iron. Journal of Nutrition 126, 1213S-1220S.

Hume, R. \& Weyers, E. (1973). Changes in leukocyte ascorbic acid during the common cold. Scottish Medical Journal 18, 3-7.

Interdepartmental Committee on Nutrition for National Defense (1963). Manual for Nutrition Surveys: Interdepartmental Committee on Nutrition for National Defense, 2nd ed. Washington, DC: US Government Printing Office.

Irvin, T. T., Chattopadhyay, K. \& Smythe, A. (1978). Ascorbic acid requirements in postoperative patients. Surgery, Gynaecology and Obstetrics 147, 49-55.

Kallner, A. B., Hartmann, D. \& Hornig, D. H. (1981). On the requirements of ascorbic acid in man: steady state turnover and body pool in smokers. American Journal of Clinical Nutrition 34, 1347-1355.

Kanai, M., Raz, A. \& Goodman, D. S. (1968). Retinol binding protein: the transport protein for vitamin A in human plasma. Journal of Clinical Investigations 47, 2025-2044.

Koj, A. (1974). Acute phase reactants: their synthesis, turnover and biological significance. In Structure and Function of Plasma Proteins, pp. 73-125 [A. C. Allison, editor]. London: Plenum Press.

Kuller, L. H., Eichner, J. E., Orchard, T. J., Grandits, G. A., McCallum, L. \& Tracy, R. P. (1991). The relation between serum albumin levels and risk of coronary heart disease in the Multiple Risk Factor Intervention Trial. American Joumal of Epidemiology 134, 1266-1277.

Macdonald, H., Stamford, S. \& McCarthy, H. D. (1993). Acute effect of peripheral interleukin- $1 \beta$ administration on macronutrient selection in the rat. Proceedings of the Nutrition Society 52, 358A.

Moser, U. \& Weber, F. (1984). Uptake of ascorbic acid by human granulocytes. International Journal of Vitamin and Nutrition Research 54, 47-53.

Natadisastra, G., Wittpenn, J. R., Muhilal, West, K. P., Mele, L. \& Sommer, A. (1988). Impression cytology: a practical index of vitamin A status. American Journal of Clinical Nutrition 48, 695-701.

Nathanail, L. \& Powers, H. J. (1992). Vitamin A status of young Gambian children: biochemical evaluation and conjunctival impression cytology. Annals of Tropical Paediatrics 12, 67-73.

Olson, J. A. (1984). Serum levels of vitamin A and carotenoids as reflectors of nutritional status. Journal of the National Cancer Institute 73, 1439-1444.

Phillips, A., Shaper, A. G. \& Whincup, P. H. (1989). Association between serum albumin and mortality from cardiovascular disease, cancer and other causes. Lancet ii, 1434-1436.

Platt, B. S. (1958). Epidemiology and clinical features of endemic beriberi. Proceedings of a Conference on Beriberi, Endemic Goitre and Hypervitaminosis A. Proceedings of the Federation of American Societies of Experimental Biology 17, Suppl. 2, 3-20.

Ramsden, D. B., Prince, H. P., Burr, W. A., Bradwell, A. R., Black, E. G., Evans, A. E. \& Hoffenberg, R. (1978). The inter-relationship of thyroid hormones, vitamin $\mathrm{A}$ and their binding proteins following acute stress. Clinical Endocrinology 8, 109-122.

Reddy, V., Bhaskaram, P., Raghuramulu, N., Milton, R. C., Rao, V., Madhusudan, J. \& Radha Krishna, K. V. (1986). Relationship between measles, malnutrition, and blindness: a prospective study in Indian children. American Journal of Clinical Nutrition 44, 924-930.

Riemersma, R. A., Wood, D. A., Macintyre, C. C. A., Elton, R. A., Gey, K. F. \& Oliver, M. A. (1991). Risk of angina pectoris and plasma concentrations of vitamins $\mathrm{A}, \mathrm{C}$, and $\mathrm{E}$ and carotene. Lancet 337, 1-5. 
Rosales, F. J., Ritter, S. J., Zolfaghari, R., Smith, J. E. \& Ross, A. C. (1996). The mechanism of inflammationinduced hyporetinemia. Virtual Elimination of Vitamin A Deficiency: Obstacles and Solutions for the Year 2000. Report of the XVII International Vitamin A Consultative Group, p. 98, Abstr. Washington, D. C. : IVACG Secretariat.

Rotruck, J. T., Pope, A. L., Ganther, H. E., Swanson, A. B., Hafeman, D. G. \& Hoekstra, W. G. (1973). Selenium: biochemical role as a component of glutathione peroxidase. Science 179, 588-590.

Sandberg, T., Cooper, E. H., Lidin-Janson, G. \& Yu, H. (1985). Fever and proximal tubular function in acute pyelonephritis. Nephron 41, 39-44.

Sauberlich, H. E., Skala, J. H. \& Dowdy, R. P. (1974). Laboratory Tests for the Assessment of Nutritional Status pp. 1-136. Boca Raton, Florida: CRC Press Inc.

Shearman, C. P. \& Gosling, P. (1988). Microalbuminaemia and vascular permeability. Lancet ii, 906-907.

Sipe, J. D. (1985). Cellular and humoral components of the early inflammatory reaction. In The Acute Phase Response to Injury and Infection, pp. 3-21 [A. H. Gordon and A. Koj, editors]. London: Elsevier.

Stephens, N. G., Parsons, A., Schofield, P. M., Kelly, F., Cheeseman, K. \& Mitchinson, M. J. (1996). Randomised control trial of vitamin $E$ in patients with coronary disease: Cambridge Heart Antioxidant Study (CHAOS). Lancet 347, 781-786.

Stephensen, C. B., Alvarez, J. O., Kohatsu, J., Hardmeier, R., Kennedy, J. I. Jr \& Gammon, R. B. Jr (1994). Vitamin $A$ is excreted in the urine during acute infection. American Journal of Clinical Nutrition 60, 388-392.

Stolzfus, R. J., Miller, K. W., Hakimi, M. \& Rasmussen, K. M. (1993). Conjunctival impression cytology as an indicator of vitamin A status in lactating Indonesian women. American Journal of Clinical Nutrition 58, 167 173.

Thurnham, D. I. (1994). $\beta$-Carotene, are we misreading the signals in risk groups? Some analogies with vitamin C. Proceedings of the Nutrition Society 53, 557-569.

Thurnham, D. I. \& Singkamani, R. (1991). The acute phase response and vitamin A status in malaria. Transactions of the Royal Society of Tropical Medicine and Hygiene 85, 194-199.

Thurnham, D. I., Singkamani, R., Kaewichit, R. \& Wongworapat, K. (1990). Influence of malaria infection on peroxyl-radical trapping capacity in plasma from rural and urban Thai adults. British Journal of Nutrition 64, 257-271.

Thurnham, D. I., Williams, N. R., Evans, A. E., Cambou, J. P. \& Howard, A. N. (1994). Plasma antioxidant nutrients in Belfast and Toulouse. Proceedings of the Nutrition Society 53, $261 \mathrm{~A}$.

Tillotson, J. A. \& Baker, E. M. (1972). An enzymatic measurement of the riboflavin status in man. American Journal of Clinical Nutrition 25, 425-431.

Vallance, S. (1986). Platelets, leukocytes and buffy layer vitamin C after surgery. Human Nutrition: Clinical Nutrition 40C, 35-41.

Wittpenn, J. R., Scheffer, C. G., Tseng, M. D. \& Sommer, A. (1986). Detection of early xerophthalmia by impression cytology. Archives of Ophthalmology 104, 237-239.

World Health Organization (1990). Severe and complicated malaria. Transactions of the Royal Society of Tropical Medicine and Hygiene 84, Suppl. 2, 1-65.

Yarnell, J. W. G., Baker, I. A., Sweetnam, P. M., Bainton, D., O’Brien, J. R., Whitehead, P. J. \& Elwood, P. C. (1991). Fibrinogen, viscosity, and white blood cell count are major risk factors for ischaemic heart disease. The Caerphilly and Speedwell collaborative heart disease studies. Circulation 83, 836-844. 